\title{
Correction: Amyloid- $\beta$ oligomers link depressive-like behavior and cognitive deficits in mice
}

\author{
J. H. Ledo - E. P. Azevedo - J. R. Clarke - F. C. Ribeiro - C. P. Figueiredo - D. Foguel • F. G. De Felice - S. T. Ferreira
}

Published online: 2 September 2020

(C) The Author(s) 2020. This article is published with open access

Correction to: Molecular Psychiatry 18, 1053-1054 (2013)

https://doi.org/10.1038/mp.2012.168

published online 27 November 2012

It has been brought to our attention that an anonymous reader raised concerns regarding the images shown in panels $1 \mathrm{k}$ and $1 \mathrm{n}$ in our study. We have carefully investigated this issue and concluded that the representative images shown in panels $1 \mathrm{k}$ and $1 \mathrm{n}$ are indeed identical. We offer our sincere apologies for this unfortunate oversight. After careful re-examination of our data, we concluded that the image shown in panel $1 \mathrm{n}$ was inadvertently replicated in panel $1 \mathrm{k}$ when the final figure was prepared for publication.
Nonetheless, and importantly, we note that this inadvertent duplication of an image did not affect the quantitative analysis of the data and corresponding statistics presented in panel 1o, and thus did not affect the conclusions of our study.

We have now prepared a revised version of Fig. 1 (displayed below), in which the incorrect image presented in panel $1 \mathrm{k}$ has been replaced by a correct image for that experimental condition. In addition, a spreadsheet containing the original raw data used to generate the graph shown in our published paper (panel 1o) and a Prism file containing the graph generated using such raw data are provided here in the Supplementary Material section.

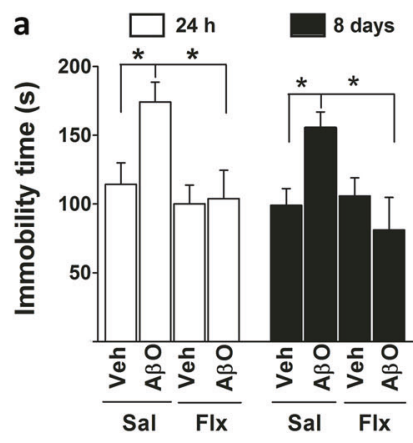

b

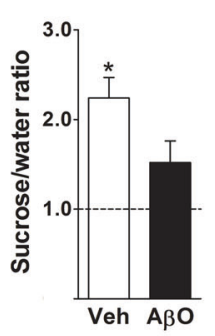

$\mathrm{A} B \mathrm{O}$
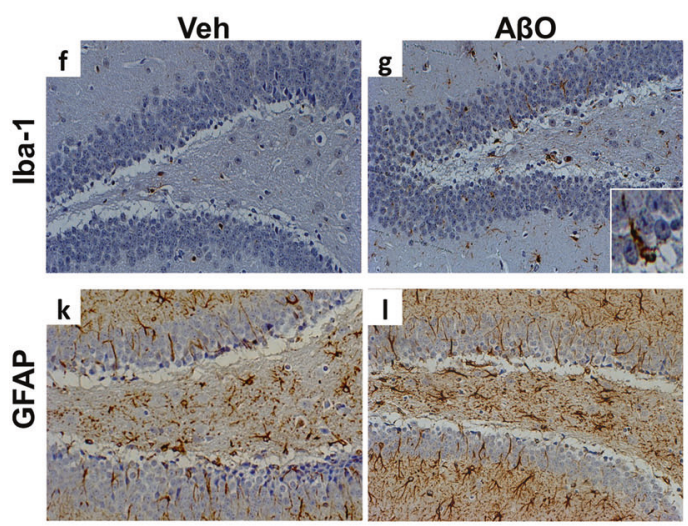

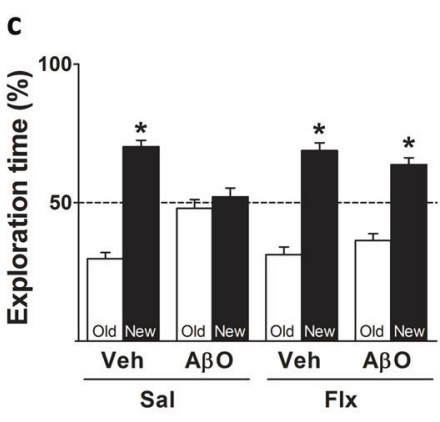

d
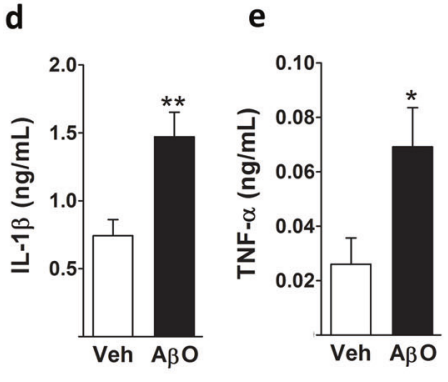
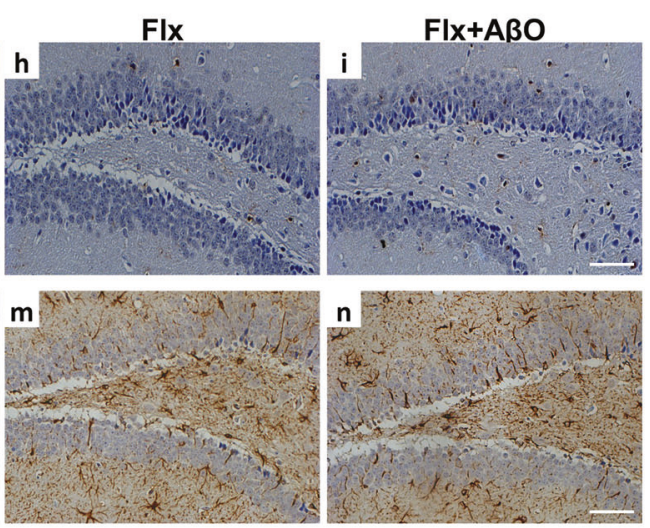

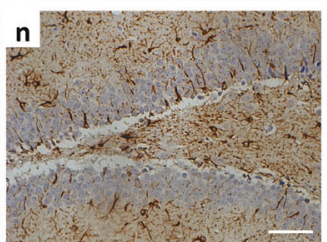

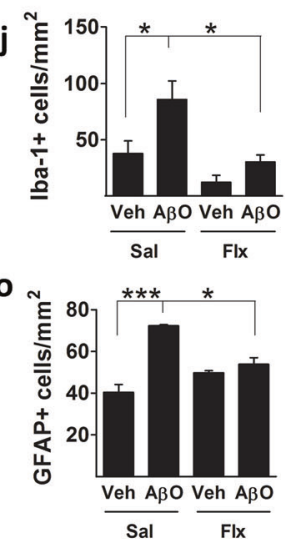

Fig. 1 
Open Access This article is licensed under a Creative Commons Attribution-NonCommercial-NoDerivatives 4.0 International License, which permits any non-commercial use, sharing, distribution and reproduction in any medium or format, as long as you give appropriate credit to the original author(s) and the source, and provide a link to the Creative Commons license. You do not have permission under this license to share adapted material derived from this article or parts of it. The images or other third party material in this article are included in the article's Creative Commons license, unless indicated otherwise in a credit line to the material. If material is not included in the article's Creative Commons license and your intended use is not permitted by statutory regulation or exceeds the permitted use, you will need to obtain permission directly from the copyright holder. To view a copy of this license, visit http://creativecommons.org/licenses/by-nc-nd/4.0/. 